\title{
MECHANISTIC VS. HOLISTIC LANGUAGE \\ LEARNING - A PARADIGM CHANGE OR PARADIGM PARALYSIS?
}

\author{
Vytenis Končius
}

University of Applied Sciences

\begin{abstract}
There are three ways to view the relationship between traditional ("mechanistic") and innovative ("holistic") second language teaching and learning: as nearing towards a paradigm shift, as an existing dialectic tension between two competing paradigms, or as a state of "paradigm paralysis". Paradigm is an overall concept accepted by a community of researchers or specialists as the main guiding principle in their endeavour. The mechanistic paradigm of second language learning regards the language acquisition process as that of conscious artificial construction of language knowledge in a learner's mind. The persistent and widespread failure of traditional second language instruction to produce fluent speakers might be attributed not only to the faults on the part of learners or teachers but also to the underlying paradigm of teaching. Is second language teaching moving towards the paradigm shift in the Kuhnian sense or are the two paradigms co-existing side by side generating fruitful discussion? Is "paradigm paralysis", i.e. entrenchment of both sides in rigid and inflexible opposition, also a reality in the field of language teaching? Our evolving understanding of language and learning urges us to compare mechanistic and holistic approaches, develop new perspectives and make informed decisions.
\end{abstract}

Keywords: second language acquisition, paradigm shift, paradigm opposition, paradigm paralysis, mechanistic and holistic paradigms.

Language learning is once complex and simple. When I think of the complexity of language learning, I'm amazed that people succeed. As a linguist, I have spent much of my life puzzling over the complexities of language, and I feel I still understand so very little about any language. Yet, people do learn new languages, not only as children, but also as adolescents and as adults. Observing that process only increases my sense of wonder. People learn far more than they are aware that they are learning. How do they do it? (Gregg Thomson "Key principles of design for an ongoing language learning program” 1998)

\section{Introduction}

Despite our new insights into the nature of language and learning, most of the traditional thinking that underlies second language teaching - courses, textbooks, school curricula, etc. - is still largely based on the concept that language acquisition is a linear, mechanical, consciously controlled, brick-by-brick building process in 
learner's mind. Learners undergo this process of formal language instruction and are expected to internalize the vocabulary and grammar presented in the curriculum. The assumption is that if this material is properly mastered and sufficient practice is carried out, this should ensure the successful acquisition of the language at the desired level (A2, B1, B2, etc.) and produce fluent speakers. According to this view, the failure of a learner to acquire the language during this process of formal instruction should be attributed either to the lack of practice, bad attendance of classes, insufficient concentration, or faults on the part of a teacher.

However, the widespread failure of many learners to acquire a second language seems to suggest that at least some of the traditional assumptions concerning how languages are acquired need to be revised. In fact, our new understanding of language and learning strongly suggests that not only first but also second language acquisition process is neither linear nor consciously controllable and trying to ensure its success by keeping it under rigorous control is an understandable, but illusory goal which may be ineffective at best or counterproductive at worst. Research suggests that learning in general and language learning in particular is not a linear, but rather a holistic process, not a process of mechanical construction, but closer to that of an organic growth. According to the British linguist Michael Lewis, the central metaphor of language is holistic - an organism, not atomistic - a machine. One of the implications of this realization is that language should not be "taught" in a sense of assembling this "machine" in learner's head, but rather allowed to organically develops under the right conditions. The main question, then, should be not how to "push" the language into a learner's mind, but how to create these "right conditions" and best aid him/her in their natural process of acquisition. Another useful insight from observation and experience is that learning is essentially the process of discovery - getting acquainted with and getting used to a language is a highly individual process, because it organically relates new information with what has already been known to the learner. Since this experience can vary greatly, the learning process and pace are by their nature highly individualistic. Attempts to control them by providing one-size-fits-all solutions and curricula not only creates the inevitable castes of "bright kids" and those lagging behind in a language classroom, but also leads to the familiar situation when despite years of formal language instruction, many learners are still unable to adequately function in a foreign language.

Are we heading towards a paradigm change in language teaching? Should the mechanistic paradigm (language is a "machine" or a building which a teacher should construct in learner's head brick-by-brick) be replaced by the holistic one (language is a "plant" or an "organism" and the process of its acquisition is that of discovery and organic growth)? Michael Lewis in his groundbreaking book "The Lexical Approach. The State of ELT and a Way Forward" suggests that even if we might not be sure about the optimal ways of teaching a second language, we do know what language and learning is not and how it does not work and as such this 
understanding might predict a possible paradigm shift:

Whether we will ever know enough about language and learning to provide fully convincing alternatives is doubtful, but we certainly do not at the moment. What we do have, however, is knowledge about language and learning which allows us to judge certain content and methodology to be better than we have had in the past $\langle\ldots>$ The Lexical Approach invites readers to dismiss, or at least radically deemphasize materials and procedures which violate either the nature of language or the nature of learning. (Lewis 1993, p. ix).

What does this paradigm change involve and most importantly - what does it imply for the traditional roles of teacher and learner and how would it impact the process of language teaching in the future?

\section{Paradigm shift}

Merriam-Webster's dictionary defines paradigm as a "philosophical and theoretical framework of a scientific school or discipline within which theories, laws, and generalizations and the experiments performed in support of them are formulated" ${ }^{1}$. In a more general usage it is usually understood as a worldview or a model explaining some phenomenon (natural, social, psychological etc.) under which a community of researchers or specialists operates. Since scientific understanding of the world and its phenomena is in constant change, changing paradigms are a natural part of the scientific process. As examples of paradigm change we can think of many instances in the old or more recent developments of science: transition from geocentric to heliocentric model in Astronomy, from Newtonian to quantum model in Physics, from unlimited growth to sustainability model in Economics, finally - from "atomistic" to holistic understanding of many phenomena: the natural world, social phenomena, human body, psychological phenomena, including our understanding of second language acquisition. This understanding of changing scientific worldview was popularised by the philosopher of science Thomas Kuhn (1922 - 1996) in his landmark book "The Structure of Scientific Revolutions" (1962). In it he analyses the process a scientific paradigm undergoes as more data is arriving and starting to challenge its established assumptions. The main steps leading to a paradigm shift, according to Kuhn, are the following:

1 https://www.merriam-webster.com/dictionary/paradigm 


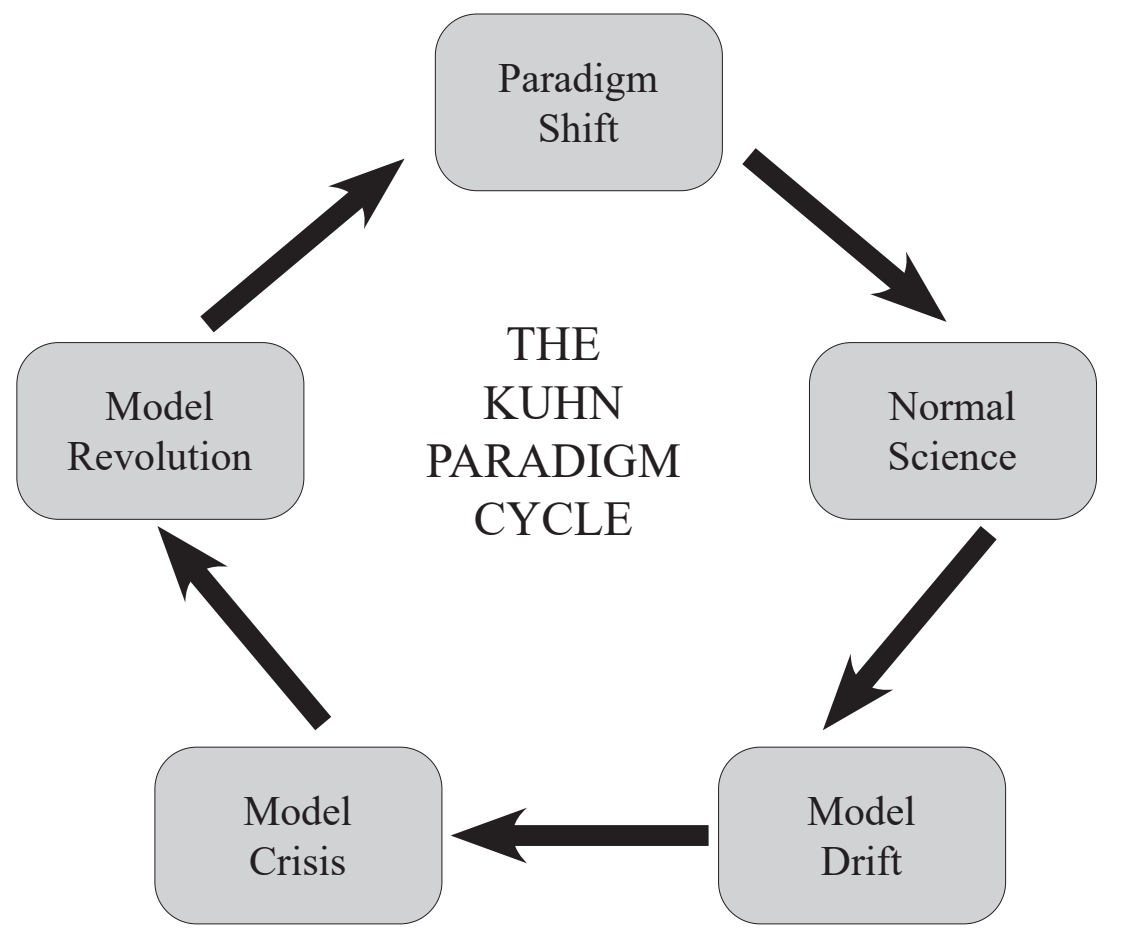

1. Scientific community usually operates under a set of "received beliefs" or paradigm. Every student who aspires to become a member of that community is "initiated" into this paradigm as a part of their rigorous education process.

2. The "normal science" which is based on these beliefs is reluctant to accept facts or new theories that challenge them.

3. When the scientific community is increasingly unable cope with the arising contradictions and to force the nature into the framework of an existing paradigm, a crisis develops.

4. As a result of this crisis, a paradigm shift occurs when a community accepts a new paradigm, which better explains the existing facts and reduces the tension. Kuhn calls this shift "a scientific revolution" - "the tradition-shattering complements to the tradition-bound activity of normal science" ${ }^{2}$

This is not always a very smooth and unchallenged process, because old ways of thinking even in the scientific community may be hard to overcome. As Kuhn himself notes:

"The transition between competing paradigms cannot be made a step at a time, forced by logic and neutral experience. $<\ldots>$ it must occur all at once (though not necessarily in an instant) or not at all." (Kuhn, 1962, p. 150)

2 Synopsis of Thomas Kuhn at https://www.uky.edu/ eushe2/Pajares/Kuhn.html 
Sometimes this change requires so much radical re-thinking of established ways or procedures that few are ready to re-invest time and energy into creating a model based on the new understanding. As Max Plank has sadly observed, "A new scientific truth does not triumph by convincing its opponents and making them see the light, but rather because its opponents eventually die, and a new generation grows up that is familiar with it." (Max Planck, Scientific autobiography, 1950, p. 33, 97)

\section{Paradigm shifts or competing paradigms? A dialectic view}

Kuhn created his model of changing paradigms mostly having in mind natural sciences. Competing paradigms may exist in various fields - in social sciences and humanities as well, including the area of second language acquisition. However, some paradigms seem to behave differently from Kuhn's model, they do not seem replace each other in a rapid paradigm shift, but to coexist side by side in perpetual conflict and opposition. In spite of the large adherence of a new paradigm, it may continue to engage in a polemics with the old one attracting criticism from the latter's adherents but neither the new one being able to totally replace an old one, nor to retreating and disappearing as an unviable hypothesis. This may be a positive thing as it generates a fruitful tension which may lead to new insights, discoveries and innovative ways of thinking.

In 1980's American linguist Stephen Krashen proposed a new paradigm to second language teaching and learning, which he called "The Natural Approach" (Krashen, Terrel, 1983). The main tenets of Krashen's new approach consisted of the following five hypotheses:

1. The Input hypothesis. We can acquire a second language simply by receiving large amounts of comprehensible input while fully concentrating on the message rather than on form. The input should be neither too difficult nor too easy: it should be largely comprehensible to a learner, but should always contain some new and unknown elements to be acquired (the so-called $i+1$ hypothesis).

2. The Acquisition-learning hypothesis. Language acquisition and language learning are two separate phenomena. Acquisition is a natural and unconscious process while learning is artificial and conscious. Most controversially, Krashen claimed that learning does not help acquisition.

3. The Monitor hypothesis. Language knowledge which we learn consciously is only useful to "monitor" our mistakes, but it does not help us become fluent.

4. The Natural Order hypothesis. There is a natural sequence in which a learner acquires grammatical patterns of a language and this order is acquired naturally with enough exposure to comprehensible input. Conscious studying of grammar rules in that order does not help to acquire them.

5. The Affective filter hypothesis. We acquire best when we are relaxed, enjoy the process and do not worry about learning. Worrying and stress diminish 
our capacity to acquire a language.

To summarise, Krashen suggested a radically new approach to language teaching, which threatens to dispense with traditional approaches of conscious and structured study of grammar and would be solely devoted to informal communication, concentrating on the message and receiving comprehensible input. Grammar, in Krashen's system, is not a prerequisite to master a language, but rather a supplement, which could be helpful to monitor learners' mistakes at the later stages once the language is already acquired.

Krashen's Natural Approach could be regarded as a new paradigm in second language teaching and learning, since it represents quite a radical break from previously accepted methodologies, which were based on the assumption that successful mastery of a second language requires first to internalize its grammar, practice it to acquire skills, supplement this knowledge with learning the vast vocabulary and only then there exists a chance of a learner developing fluency. However, due to the persistent failure of this system to deliver satisfactory results, as predicted by the Kuhnian model, the tension in the "normal science" started to build up, the need arose to review the existing second language teaching paradigms and Krashen's suggestion came as a "paradigm shift", proposing a new way of looking at things. Incidentally, Krashen and Terrel did not regard their method as anything new, rather they called their method "traditional" and the grammar and conscious study-based methods as new inventions that have mislead teachers and learners ${ }^{3}$.

Krashen's ideas have caused a lot of heated debates and considerable backlash both at the time when they were first formulated (late 1970's - early 1980's) and in our present day, as evidenced by the amount of attention they received in the articles and publications throughout decades: nearly every author writing on the problems of SLA during several decades seems to be compelled to spend some time discussing the major points raised by Krashen. A lot of critics tend to reject Krashen's views as too radical - there is a widespread opinion that Krashen has gone too far and that traditional conscious language study could not be totally replaced by input-based learning.

Thus, in terms of the concept of paradigms, it seems that the Kuhnian paradigm shift did not occur, rather we are having a case of two paradigms existing side by side: the "traditional", grammar and conscious study-based learning by concentrating on form versus the "Natural Approach" based on absorbing comprehensible input by concentrating on the message. Both paradigms have their adherents and supporters and the tension between the two seem to be productive for our deepening understanding of second language acquisition process. Such tensions

3 Synopsis of the Natural Approach at https://www2.vobs.at/ludescher/alternative\%20methods/ natural_approach.htm 
are not to be avoided, but welcomed as an opportunity to try and test the viability of each paradigm and in this way to deepen our understanding.

However, the biggest obstacles to fruitful discussions is not paradigm shift or paradigm conflict, but the so-called "paradigm paralysis" which is similar to what in Psychology is often termed as "confirmation bias". Oxford Encyclopedia of Terms defines it as the "refusal or inability to think or see outside or beyond the current framework or way of thinking or seeing or perceiving things. Paradigm paralysis is often used to indicate a general lack of cognitive flexibility and adaptability of thinking" ${ }^{4}$. Paradigm paralysis entrenches one in their own rigid ways of thinking without allowing to see the things from a different perspective or allowing to be flexible in developing alternative approaches. In the domain of language teaching, paradigm paralysis would represent dogmatic adherence to one's paradigm without being sufficiently open-minded and flexible to react to the real challenges and see what is working and what is not. One might assume that a large part of failure for second language teaching to deliver satisfactory results throughout the decades might be attributed at least in part to the "paradigm paralysis" - inflexibility and unwillingness to see beyond one's familiar and customary ways. One might add that it is not only the "old paradigm" may be the cause of the paralysis: blind adherence to the "natural" or "holistic" approach might be as detrimental if not counterbalanced by a healthy critical analysis.

Thus, where is language acquisition theory and practice at the moment? Is it undergoing a paradigm shift? Does it represent a dialectic pair of opposite and competing paradigms? Or is it in a state of paradigm paralysis? It would probably be safe to say that in the vast world of today's language teaching and learning one can find instances for all of them at once: there are sufficient examples when language is being taught using ineffective "traditional" methods as well as various new experimentations with innovative methods (possibly, not always successful). Unfortunately, there are also sufficient instances of inflexibility and stagnation thus diminishing the quality and effectiveness of language teaching.

\section{Mechanistic versus holistic paradigms in language acquisition:}

In the belief that clarifying the two competing paradigms would provide a clearer understanding of the current situation, we would like to provide a point-bypoint comparison of the main underlying assumptions of mechanistic and holistic paradigms in the following tables. Whether the holistic one is on the way of replacing the other in the process of coming paradigm shift or whether the two should exist in constant opposition and fruitful conflict remains to be seen, but it seems useful to clarify their main tenets, shedding light on their possible benefits and drawbacks in an attempt to find a productive solution to the difficulties one encounters.

4 https://www.oxford-review.com/tag/paradigm/ 


\begin{tabular}{|c|c|}
\hline Mechanistic paradigm: & Holistic paradigm: \\
\hline $\begin{array}{l}\text { - Language acquisition is essentially a } \\
\text { process of constructing a whole from parts: } \\
\text { fluent speech is constructed from mastering } \\
\text { and practicing grammar structures and } \\
\text { vocabulary. } \\
\text { - Language development is linear, consciously } \\
\text { controlled, mechanic, brick-by-brick } \\
\text { construction process in learner's head. } \\
\text { - Language is being taught. } \\
\text { - Language is an abstract idealization to be } \\
\text { mastered: thus the emphasis on perfection, } \\
\text { too much concentration on error correction, } \\
\text { and resulting stressful atmosphere, learners' } \\
\text { fear to speak. } \\
\text { - Grammar is at the centre. Language consists } \\
\text { of grammar rules (i.e. the underlying } \\
\text { structure) and vocabulary (the "bricks"). } \\
\text { Learning to speak resembles the process } \\
\text { of assembling a mechanical structure from } \\
\text { grammar rules and words (hence the epithet } \\
\text { "mechanistic"). }\end{array}$ & $\begin{array}{l}\text { - Language acquisition is a growth process } \\
\text { similar to that of a plant which given the right } \\
\text { conditions evolves by itself: the basis for } \\
\text { fluent speech develops as a result of exposure } \\
\text { to meaningful messages and understanding } \\
\text { them. } \\
\text { - Language development is non-linear, holistic, } \\
\text { organic, chaotic, largely subconscious and } \\
\text { independent of teacher's control. } \\
\text { - Language is being discovered by the learner. } \\
\text { - Language is a practical personal resource } \\
\text { to be used. Focus on communication. } \\
\text { Realization that even if imperfectly mastered } \\
\text { it is a useful resource. Enjoying even the } \\
\text { most imperfect attempts to communicate. } \\
\text { - Vocabulary is at the centre. Language } \\
\text { consists of grammaticalised lexis and not of } \\
\text { lexicalized grammar. Sentences and phrases } \\
\text { are not constructions assembled from smaller } \\
\text { elements, but larger wholes split up into } \\
\text { constituent parts and then re-assembled for } \\
\text { future uses. }\end{array}$ \\
\hline
\end{tabular}

How does this paradigm change reflect in the teaching process? How does it reflect on the role of a teacher? One of the reasons why many teachers might be reluctant to accept the new paradigm might be the sense of insecurity and fear that with the changing understanding, their role will become increasingly uncertain and obsolete. Developing technologies and their impact on the traditional ways of language teaching and learning also do not contribute to alleviating this fear. However, even though the holistic paradigm does change the role of a teacher, it by no means becomes less important. One has to learn to look at it in new ways and find areas where teacher can be even more indispensable and their help can be even more valuable and meaningful than in the traditional classroom. The following are some suggestions how teachers can rethink their role and find their place in the holistic paradigm: 


\begin{tabular}{|c|c|}
\hline Mechanistic paradigm: & Holistic paradigm: \\
\hline $\begin{array}{l}\text { - Teacher's role - a constructor of the } \\
\text { edifice of language in learner's head } \\
\text { taking the whole responsibility for a } \\
\text { learner's language development. } \\
\text { - Teacher is an omniscient grammar expert } \\
\text { and an absolute authority as far as rules } \\
\text { and correctness are concerned. } \\
\text { - Teacher concentrates on the form, making } \\
\text { language learning process artificial and } \\
\text { unnatural (e.g. artificial dialogues to } \\
\text { illustrate some new grammar rule, etc.). } \\
\text { - Teacher oversees and controls the P-P-P } \\
\text { (Present-practice-produce) process: } \\
\text { present new material, control learners' } \\
\text { practice, expect flawless presentation } \\
\text { and correcting lingering mistakes. } \\
\text { - Teacher limits and controls the input } \\
\text { learners are exposed to. Authentic real- } \\
\text { life input is avoided as it does not allow } \\
\text { to effectively control the process of new } \\
\text { vocabulary learning. } \\
\text { - Teacher tries to build the language in } \\
\text { learners' minds "bottom-up" (manually } \\
\text { assembling larger units from smaller } \\
\text { parts). }\end{array}$ & $\begin{array}{l}\text { - Teacher is a facilitator and a guide to a learner's } \\
\text { journey of discovery. Teacher does not teach the } \\
\text { learner, but opens the way and empowers them. } \\
\text { - Teacher's knowledge may not be perfect and } \\
\text { he/she is comfortable recognizing it. However, } \\
\text { teacher is doing his/her best helping learners with } \\
\text { the most daunting task of every language learner: } \\
\text { to navigate in the vast sea of new vocabulary. } \\
\text { - Teacher is a natural conversation partner and the } \\
\text { main focus is on real-life communication. Focus } \\
\text { on form is recognized as a supplement aiding in } \\
\text { understanding and self-expression, but does not } \\
\text { take a centre-stage. } \\
\text { - Teacher is present with learner's O-H-E } \\
\text { (Observing-hypothesizing-experimenting) ready } \\
\text { to provide all the help and support learners need. } \\
\text { - Teacher does not try to restrict and control } \\
\text { vocabulary input. All language which we produce } \\
\text { is based on language which we have previously } \\
\text { met. If we expect learners to be fluent, providing } \\
\text { them with limited amount of input is counter- } \\
\text { productive. } \\
\text { - Teacher helps learners to understand the language } \\
\text { top-down (breaking down the larger units - texts } \\
\text { and sentences - and raising awareness of the } \\
\text { elements for future re-use). }\end{array}$ \\
\hline
\end{tabular}

As we can see, teacher's role in the holistic paradigm does not diminish, if anything, there are areas where it becomes much more interesting and meaningful than anything performed under the traditional approach. Finally, one has to address some fears and misconceptions what holistic model is or is not:

- Rejection of grammar. Grammar is not rejected as such (i.e. it is not "forbidden" to teach grammar). However, its place in learning process is adjusted - it is the awareness raising of grammar patterns after the language has been acquired, not studying them before they are acquired. In fact awareness raising (i.e. noticing) activities are essential for accuracy and teacher's task is to help learners notice. Therefore, although the essential focus is on the message, conscious attention to form is encouraged and conscious learning as such is not rejected.

- Chaotic syllabus. One common fear might be that syllabus based on the new paradigm would inevitably be chaotic - no grammar sequence, no gradual introduction of vocabulary of increasing difficulty. However, it need not to be so - even if syllabus does not follow a formal grammar-based sequence, it is based on increasing complexity of input (Krashen's i+1 hypothesis). Besides, Krashen's Natural Order hypothesis predicts that we acquire grammar structures 
not as a result of the sequence they are taught in the grammar syllabus, but due to exposure to comprehensible input. If these theories are true, then teaching strictly grammar-structured syllabus loses it's meaning in any case.

- Diminishing role of a teacher. As mentioned above, far from diminishing, teacher's role remains to be essential as a facilitator and a guide of a learner who navigates their individual and fascinating journey of language discovery and acquisition.

\section{Conclusions}

Language teaching, like all other areas of human endeavour, is not immune to the process of trial and error. Looking at long-established language teaching practices and traditions in terms of paradigm change helps us develop new perspectives to the familiar ways of doing things and generate useful debate. Our understanding of the nature of language and learning is constantly evolving - and so must the methods of language teaching and learning. Failing to do so leaves us with inefficient language teaching, wasted money and time and poor results. In today's world of quickly developing technologies and the Internet, a language teacher can no longer be an omniscient authority and an all-powerful controller of the language acquisition process. Rather, a teacher should be regarded as a companion and a guide accompanying students in their journey of discovery and helping them not to get lost in the new world. Thus, a teacher's role remains essential, but should be radically rethought. Holistic paradigm of language acquisition provides us with a new perspective which would enrich our language learning experience in today's increasingly multilingual and multicultural world.

\section{Literature}

Krashen, S., Terrell, T. (1983). The Natural Approach: Language Acquisition in the Classroom. Alemany Press

Kuhn, T. (1996). The Structure of Scientific Revolutions. The University of Chicago Press 3rd (third) edition

Lewis, M. (1993). The Lexical Approach: The State of ELT and a Way Forward. Language Teaching Publications

Planck, M. (2014). Scientific autobiography: and Other papers, Open Road Media

Richards, J., Rogers, T. (2001). Approaches and Methods in Language Teaching (2nd ed.). Cambridge University Press.

Oxford Encyclopedia of Terms https://www.oxford-review.com/oxfordreview-encyclopaedia-terms/paradigm-paralysis/

The Structure of Scientific Revolutions - Outline and Study Guide prepared by Professor Frank Pajares. Emory University https://www.uky.edu/ eushe2/Pajares/ Kuhn.html 


\title{
MECHANISTINIS IR HOLISTINIS KALBŲ MOKYMAS - PARADIGMŲ KAITA AR PARADIGMOS SĄSTINGIS?
}

\author{
Vytenis Končius \\ Vilniaus kolegija
}

\begin{abstract}
Santrauka
Tradicinès (mechanistinès) ir novatoriškos (holistinès) antrosios kalbos mokymo ir mokymosi paradigmų santykị galima matyti trimis būdais: kalbų mokymo metodika artèja link paradigmos pokyčio, egzistuoja konfliktas ir dialektinè ịtampa tarp dviejų konkuruojančių paradigmų arba „,paradigmos sąstingis“ (paradigm paralysis). Paradigma yra bendra koncepcija, kurią tyrejjų ar specialistų bendruomenė priima kaip pagrindinị jų veiklą organizuojanti principą. Mechanistinè antrosios kalbos mokymosi paradigma laiko kalbos mokymosi procesą sąmoningu ir dirbtiniu kalbos žinių konstravimu besimokančiojo galvoje. Nuolatinis ir plačiai paplitęs tradicinès kalbos mokymo metodikos negebejjimas pasiekti gerų rezultatų gali būti siejamas ne tik su besimokančiųjų ar mokytojų klaidomis, bet ir su pagrindine kalbų mokymo paradigma. Ar antrosios kalbos mokymas eina link paradigmos pokyčio, ar abi paradigmos egzistuoja viena greta kitos ir kelia vaisingą diskusiją? Ar ,paradigmos sąstingis“, t. y. abiejų pusių ịtvirtinimas griežtoje ir nelanksčioje opozicijoje, taip pat yra kalbos mokymo realybė? Tobulèjantis mūsų supratimas apie kalbos ar mokymosi prigimtį ragina palyginti mechanistinị ir holistinị požiūrị, kurti naujas perspektyvas ir priimti pagristus sprendimus.
\end{abstract}

Reikšminiai žodžiai: antrosios kalbos mokymasis, paradigmos pasikeitimas, mechanistinè ir holistinè paradigma. 


\section{AUTORIAUS LYDRAŠTIS}

Autoriaus vardas, pavardè: Vytenis Končius

Mokslo laipsnis ir vardas: magistras

Darbo vieta ir pareigos: Vilniaus kolegija, lektorius

Autoriaus mokslinių interesų sritys: svetimos kalbos mokymasis, kalbų mokymo metodika, kalba ir kultūra, tarpkultūrinè komunikacija

Telefonas ir el. pašto adresas: +370 61431 701, v.koncius@vvf.viko.lt 